\title{
SISTEM PENDUKUNG KEPUTUSAN PENERIMAAN ASISTEN LABORATORIUM MENGGUNAKAN METODE MULTI FACTOR EVALUATION PROCESS (MFEP)
}

\author{
Painem $^{1}$, Hari Soetanto ${ }^{2}$ \\ Prodi Sistem Informasi, Fakultas Teknologi Informasi \\ Universitas Budi Luhur, Jakarta \\ 1)painem@budiluhur.ac.id \\ 2) Prodi Teknik Informatika, Fakultas Teknologi Informasi \\ Universitas Budi Luhur, Jakarta \\ 2)hari.soetanto@budiluhur.ac.id
}

\begin{abstract}
Abstrak
Asisten LAB ICT merupakan mahasiswa Fakultas Teknologi Informasi dan Fakultas Ekonomi dan Bisnis yang aktif. Asisten Laboratorium mempunyai tugas mendampingi dosen pada saat dosen mengajar praktikum di LAB ICT, dan harus memahami materi praktikum dosen yang sedang mengajar, dan harus mampu memperbaiki komputer yang bermasalah. Asisten bukan jabatan permanen di LAB ICT. Asisten Lab bukan merupakan jabatan yang permanen, sehingga setiap tahun ajaran baru dibuka pendaftaran calon asisten. Banyak mahasiswa yang mendaftar menjadi calon asisten tetapi jumlah calon asisten yang diterima terbatas. Untuk menjadi asisten Lab ada beberapa kriteria yang dijadikan sebagai penilaian, yaitu nilai hardware, nilai psikotes, nilai kompetensi, nilai wawancara, nilai project1, nilai project2 dan nilai absensi. Untuk menentukan asisten yang diterima berdasarkan beberapa kriteria diatas belum ada metode tertentu dalam mengambil keputusan. Untuk membantu dalam mengambil keputusan maka dibuat sistem pendukung keputusan untuk penentuan penerimaan Asisten Lab. Metode yang digunakan digunakan dalam sistem pendukung keputusan adalah Multi Factor Evaluation Process (MFEP). Prototype yang dibuat menggunakan bahasa pemrograman PHP.
\end{abstract}

Kata kunci: MFEP, SPK, Penerimaan Asisten, Pendukung Keputusan

\section{Abstract}

The LAB ICT Assistant is an active Information Technology and Faculty of Economics and Business student. The Laboratory Assistant has the task of assisting the lecturer when the lecturer teaches practicum at LAB ICT, and must understand the lecturer practicum material that is teaching, and must be able to repair the problematic computer. Assistants are not permanent positions in LAB ICT. The Lab Assistant is not a permanent position, so that every new school year the registration of prospective assistants is opened. Many students register to be prospective assistants but the number of prospective assistant candidates is limited. To become a Lab assistant there are several criteria that are used as assessments, namely hardware value, psychological value, competency value, interview value, project1 value, project value and attendance value. To determine the assistants who are accepted based on the above criteria there is no particular method in making decisions. To assist in making decisions, a decision support system is made for determining the acceptance of the Lab Assistant. The method used in decision support systems is the Multi Factor Evaluation Process (MFEP). The prototype is made using the PHP programming language.

Keywords: MFEP, DSS, Lab Assistant, Decision Support

\section{PENDAHULUAN}

Lab ICT merupakan Laboratorium komputer pusat yang digunakan untuk kuliah praktikun Fakultas Teknologi Informasi, Fakultas Ekonomi dan Bisnis, Fakultas Ilmu Komunikasi, Fakultas Teknik di Universitas Budi Luhur. Lab ICT juga digunakan untuk mendukung kegiatan Pengabdian Kepada Masyarakat bagi Dosen Universitas Budi Luhur. Lab ICT saat ini dibawah Direktorat Digitalisasi Penunjang Akademik.

Lab ICT saat ini mempunyai 13 ruang praktikum. Masing-masing ruangan praktikum berkapasitas 35 komputer. Mahasiswa yang 
menggunakan Lab ICT untuk praktikum kurang lebih 12.000 mhs setiap harinya. Jumlah Asisten Lab ICT saat ini hanya 22 Asisten. Jumlah tersebut masih kurang untuk memenuhi kebutuhan LAB ICT. Asisten bukan merupakan jabatan yang permanen. Sehingga setiap tahun ajaran baru ada pembukaan pendaftaran asisten untuk mahasiswa Fakultas Teknologi Informasi dan Fakultas Ekonomi dan Bisnis. Peminat untuk menjadi asisten lab banyak, kurang lebih 20-45 pendaftar setiap tahun ajaran baru. Tetapi tidak semua peminat akan menjadi asisten.

Penentuan menjadi asisten ada beberapa kriteria dalam penilaiaan antara lain : Nilai Hardware, Nilai Psikotes, Nilai Kompetensi, Nilai Wawancara, Nilai Project1,Nilai Project2 dan nilai Absensi. Banyaknya kriteria dalam penentuan penerimaa asisten maka membutuhkan waktu lama dalam perhitungannya dan belum ada metode yang digunakan untuk penentuan penerimaan asisten.

Berdasarkan latar belakang diatas maka dibutuhkan sistem pendukung keputusan untuk penentuan penerimaan asisten. Metode yang digunakan dalam sistem pendukung keputusan penentuan penerimaan asisten adalah Metode Multi Factor Evaluation Process. Sistem pendukung keputusan yang dibuat diharapkan dapat membantu menyelesaikan permasalahan dalam penentuan penerimaan asisten lab.

Penelitian sistem pendukung keputusan dengan metode MFEP sudah banyak dilakukan. Sebagai contoh Hutabri (2015) mengembangkan SPK dalam pemilihan kelas unggul menggunakan metode MFEP. Selanjutnya Andoko dkk. menerapkan metode MFEP pada sistem pendukung keputusan penentuan kelayakan pemberi pinjaman (Andoko, Alfiarini, \& Yanto, 2018) dan Djunaedi dkk juga mengembangkan Sistem Pendukung Keputusan Penilaian Kinerja Pegawai (Djunaedi, Subiyakto, \& Fetrina, 2017). Tabel 1 menyajikan beberapa penelitian terkait penerapan metode MFEP dalam SPK.

Konsep Sistem Pendukung Keputusan (SPK) atau Decision Support System pertama kali diungkapkan pada awal tahun 1971 oleh Michael S. Scott Morton (Turban, 2001) dengan istilah Management Decision System. Menurut Kusrini, pada (Turaina, Gustia E, \& Cici, 2017) SPK merupakan sistem informasi interaktif yang menyediakan informasi, pemodelan dan pemanipulasian data. SPK berfungsi membantu pengambil keputusan dengan memberikan alternatif-alternatif keputusan yang tepat.

Tabel 1. Penelitian Terkait Penerapan Metode MFEP dalam SPK

\begin{tabular}{|c|c|c|c|c|c|}
\hline No & Peneliti & Metode & Judul & Kriteria & Kesimpulan \\
\hline 1. & $\begin{array}{l}\text { (T. Henny } \\
\text { Febriana } \\
\text { Harumy, } \\
\text { 2016) }\end{array}$ & MFEP & $\begin{array}{l}\text { Sistem penunjang } \\
\text { keputusan penentuan } \\
\text { jabatan manager } \\
\text { menggunakan metode } \\
\text { MFEP pada CV. SAPO } \\
\text { DURIN }\end{array}$ & $\begin{array}{l}\text { Kedisiplinan }(0,2) \\
\text { Keaktifan }(0,15) \\
\text { Total Anggota }(0,3) \\
\text { Jumlah Anggota }(0,25) \\
\text { Kegigihan }(0,15)\end{array}$ & $\begin{array}{l}\text { Aplikasi ini digunakan } \\
\text { untuk memudahkan } \\
\text { perusahaan dalam } \\
\text { menentukan siapa yang } \\
\text { berhak dipromosikan } \\
\text { sebagai manajer }\end{array}$ \\
\hline 2. & $\begin{array}{l}\text { (Purnomo, } \\
\text { Nurdin, \& } \\
\text { Nangi, 2017) }\end{array}$ & MFEP & $\begin{array}{l}\text { Penerapan Multi Factor } \\
\text { Evaluation Process } \\
\text { (MFEP) Untuk Penilaian } \\
\text { Guru (Studi Kasus: Man } \\
1 \text { Kota Kendari) }\end{array}$ & $\begin{array}{l}\text { Tanggungjawab(1-4) } \\
\text { Kejujuran }(1-4) \\
\text { Kerjasama }(1-4) \\
\text { Kedisplinan }(1-4) \\
\text { Kehadiran }(1-4)\end{array}$ & $\begin{array}{l}\text { Perhitungan yang } \\
\text { dihasilkan oleh sistem } \\
\text { adalah sesuai dengan } \\
\text { hasil pengujian yang } \\
\text { dihasilkan melalui } \\
\text { perhitungan yang } \\
\text { dilakukan secara manual }\end{array}$ \\
\hline 3 & $\begin{array}{l}\text { (Diwanda et } \\
\text { al., 2016) }\end{array}$ & MFEP & $\begin{array}{l}\text { Sistem Penunjang } \\
\text { Keputusan Penilaian } \\
\text { Kinerja Karyawan } \\
\text { menggunakan metode } \\
\text { MFEP pada PT.Konsuil } \\
\text { Wilayah Sulawesi } \\
\text { Tenggara }\end{array}$ & $\begin{array}{l}\text { Kecakapan (4) } \\
\text { Watak dan Tingkah } \\
\text { Laku (5) } \\
\text { Loyalitas (5) }\end{array}$ & $\begin{array}{l}\text { Dengan adanya aplikasi } \\
\text { ini pengambil keputusan } \\
\text { dapat memberikan } \\
\text { penilaian kinerja } \\
\text { karyawan secara obyektif } \\
\text { dengan menimbang } \\
\text { berbagai faktor yang } \\
\text { mempunyai pengaruh } \\
\text { penting terhadap } \\
\text { alternatif pilihan } \\
\text { pengambil keputusan }\end{array}$ \\
\hline 4. & $\begin{array}{l}\text { (Hutabri, } \\
\text { 2015) }\end{array}$ & MFEP & $\begin{array}{l}\text { SPK dalam pemilihan } \\
\text { siswa kelas unggul }\end{array}$ & $\begin{array}{l}\text { 1. Administrasi: Nilai } \\
\text { UN }(0,40) \text {, Piagam }\end{array}$ & $\begin{array}{l}\text { Sistem Penunjang } \\
\text { Keputusan dalam }\end{array}$ \\
\hline
\end{tabular}




\begin{tabular}{lllll}
\hline No Peneliti & Metode & Judul & Kriteria & Kesimpulan \\
\hline & menggunakan metode & $(0,60)$ & Pemilihan Calon Siswa \\
& MFEP di SMPN 2 SOLOK & 2. Akademik: & Kelas Unggul yang dibuat \\
& & Pengetahuan & telah membantu kepala \\
& & Umum $(0,40)$, IPA & $\begin{array}{l}\text { Sekolah dalam menerima } \\
\text { informasi dan mengambil }\end{array}$ \\
& & $(0,60)$ & keputusan dalam \\
& & 3. Wawancara: Tata & keputal \\
& & Krama $(0,40)$, & penerimaan calon siswa \\
& & Kepribadian $(0,60)$ & kelas unggul dengan \\
& & & cepat dan tepat
\end{tabular}

Metode MFEP (Multi Factor Evaluation Process) merupakan metode yang menjadi fundamental dari pengembangan metode pada Sistem Pendukung Keputusan (Latif, Jamil, \& Abbas, 2018). Teknik penyelesaian metode ini yaitu dengan penilaian subyektif dan intuitif terhadap indikator atau faktor penyebab dari sebuah masalah yang dianggap penting. Pertimbangan - pertimbangan tersebut yaitu dengan memberikan bobot (weighting system) berdasarkan skala prioritas berdasarkan tingkat kepentingannya. Adapun algoritma penyelesaian metode ini yaitu :

1. Langkah 1 : Mendefinisikan terlebih dahulu kriteria - kriteria atau faktor-faktor yang menyebabkan masalah beserta bobotnya

2. Langkah 2 :Menghitung nilai Bobot Evaluasi (NBE)

3. Langkah 3 :Menghitung Total Bobot Evaluasi (TBE)

4. Langkah 4 : Lakukan perangkingan untuk mendapatkan keputusan

Adapun rumus yang digunakan untuk menghitung nilai (NBE) pada metode MFEP menggunakan Persamaan (1).

$N B E=N B F * N E F$

Keterangan :

NBE : Nilai Bobot Evaluasi

NBF : Nilai Bobot Factor

NEF : Nilai Evaluasi Factor

Sementara itu, Persamaan (2) merupakan rumus yang digunakan untuk menghitung nilai TBE pada metode MFEP.

$T B E=\sum_{n=1}^{k} \operatorname{NBE}(n)$

Keterangan :

TBE : Total Bobot Evaluasi

NBE : Nilai Bobot Evaluasi

$\mathrm{k}$ : jumlah kriteria

\section{METODE PENELITIAN}

\section{Langkah Penelitian}

Untuk menyelesaikan permasalahan, dalam penelitian ini dilakukan beberapa langkah dan metode penelitian, seperti disajikan pada Gambar 1 dan dijelaskan sebagai berikut:

a. Studi Pustaka

Metode ini dilakukan untuk mengumpulkan data dengan mencari dan membaca buku-buku referensi, jurnal, paper dan karya ilmiah lainnya yang dapat menunjang penelitian ini.

b. Analisis Dokumen

Dokumen yang diperoleh kemudian dipelajari dan dianalisis untuk mengetahui bentuk sistem cara kerja yang akan dibangun.

c. Rancangan Aplikasi / Prototype

Metode ini dilakukan dengan membuat rancangan layar, flowchart, database dan lainlain sesuai dengan hasil analisis.

d. Pembuatan Prototype

Rancangan sistem yang sudah dibuat akan diimplementasikan berdasarkan hasil analisis. Kemudian hasil analisa akan dituangkan dalam kode-kode dengan menggunakan bahasa pemrograman tertentu.

e. Pengujian dan Analisis

Setelah sistem selesai dibangun, maka dilakukan uji coba terhadap sistem yang dibangun. Pengujian dilakukan dengan metode black box dan pengujian persepsional dengan ISO 9126.

f. Pembuatan Laporan dan Publikasi

Berdasarkan hasil pengujian yang dilakukan, dibuat laporan penelitian dan publikasi hasil penelitian. 


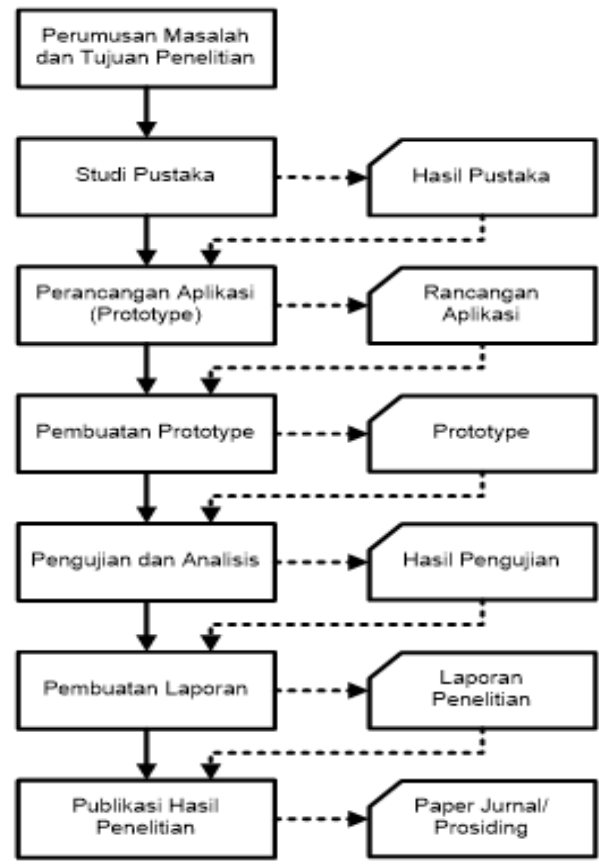

Gambar 1. Langkah Penelitian

\section{Kerangka Pikir}

Gambar 2 menampilkan kerangka pikir yang digunakan dalam penelitian ini. Kerangka pikir mencakup analisis terhadap kondisi saat ini di Laboratorium ICT Universitas Budi Luhur. Selanjutnya dirumuskan permasalahan penelitian dan rancangan solusi dengan menerapkan metode MFEP dalam Sistem Pendukung Keputusan.

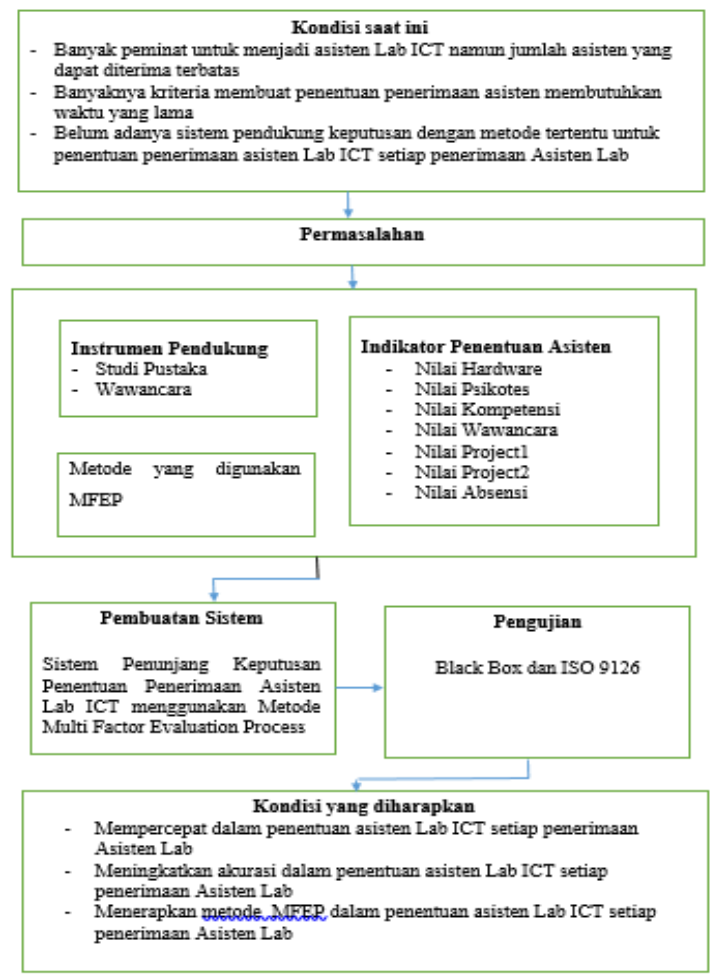

Gambar 2. Kerangka Pikir

\section{HASIL DAN PEMBAHASAN}

\section{Perhitungan MFEP secara Manual}

Pada Tabel 2 disajikan kriteria - kriteria yang dibutuhkan dalam penentuan penerimaan Asisten Lab ICT

Tabel 2. Kriteria Penerimaan Asisten Lab ICT

\begin{tabular}{cl}
\hline Kode Kriteria & \multicolumn{1}{c}{ Nama kriteria } \\
\hline K001 & Nilai Hardware \\
K002 & Nilai Psikotes \\
K003 & Nilai Kompetensi \\
K004 & Nilai Wawancara \\
K005 & Nilai Project 1 \\
K006 & Nilai Project 2 \\
K007 & Nilai Absensi \\
\hline
\end{tabular}

Sementara itu, pada Tabel 3 ditampilkan bobot yang akan digunakan untuk setiap alternatif adalah dibutuhkan dalam penentuan penerimaan Asisten Lab ICT

Tabel 3. Pembobotan Kriteria

\begin{tabular}{cll}
\hline Kode Kriteria & Alternatif & Bobot \\
\hline K001 & Nilai Hardware & $20 \%$ \\
K002 & Nilai Psikotes & $10 \%$ \\
K003 & Nilai Kompetensi & $20 \%$ \\
K004 & Nilai Wawancara & $10 \%$ \\
K005 & Nilai Project 1 & $10 \%$ \\
K006 & Nilai Project 2 & $10 \%$ \\
K007 & Nilai Absensi & $20 \%$ \\
\hline
\end{tabular}

Langkah selanjutnya adalah melakukan penilaian untuk setiap alternatif, dalam hal ini calon asisten untuk setiap kriteria. Tabel 4 merupakan hasil penilaian calon Asisten berdasarkan berdasarkan test yang sudah diikuti.

Tabel 4. Nilai Alternatif

\begin{tabular}{|c|c|c|c|c|c|c|c|c|}
\hline $\begin{array}{l}\mathbf{N} \\
\mathbf{o}\end{array}$ & Nama & $\begin{array}{l}\mathbf{N} \\
\mathbf{H} \\
\end{array}$ & $\begin{array}{l}\text { NP } \\
\text { S }\end{array}$ & $\begin{array}{l}\mathbf{N} \\
\mathbf{K}\end{array}$ & $\begin{array}{l}\mathbf{N} \\
\mathbf{W}\end{array}$ & $\begin{array}{l}\text { NP } \\
1\end{array}$ & $\begin{array}{l}\text { NP } \\
2 \\
\end{array}$ & $\begin{array}{l}\mathbf{N} \\
\mathbf{A}\end{array}$ \\
\hline 1. & Irennada & 60 & 65 & 75 & 72 & 60 & 60 & 90 \\
\hline 2. & $\begin{array}{l}\text { Nurul } \\
\text { Azzahra }\end{array}$ & 65 & 67 & 70 & 62 & 60 & 60 & 94 \\
\hline 3. & $\begin{array}{l}\text { Erika Nur } \\
\text { Komala } \\
\text { sari }\end{array}$ & 80 & 66 & 65 & 60 & 60 & 60 & 93 \\
\hline 4. & Amirudin & 68 & 66 & 60 & 70 & 69 & 62 & 89 \\
\hline 5. & $\begin{array}{l}\text { M. Verdi- } \\
\text { ansyah }\end{array}$ & 90 & 67 & 70 & 74 & 76 & 90 & 86 \\
\hline 6. & $\begin{array}{l}\text { Nur Fahmi } \\
\text { Aziz }\end{array}$ & 76 & 50 & 70 & 68 & 60 & 65 & 84 \\
\hline 7. & $\begin{array}{l}\text { Muhamad } \\
\text { Satrio } \\
\text { Aditomo }\end{array}$ & 75 & 55 & 80 & 65 & 73 & 0 & 83 \\
\hline 8 & $\begin{array}{l}\text { Selfiana } \\
\text { Halfiana }\end{array}$ & 77 & 65 & 60 & 65 & 69 & 60 & 81 \\
\hline 9 & $\begin{array}{l}\text { Kamil } \\
\text { Salim }\end{array}$ & 75 & 65 & 60 & 65 & 70 & 60 & 79 \\
\hline
\end{tabular}

122 


\begin{tabular}{lllllllll}
\hline $\mathbf{N}$ & Nama & $\mathbf{N}$ & $\mathbf{N P}$ & $\mathbf{N}$ & $\mathbf{N}$ & $\mathbf{N P}$ & $\mathbf{N P}$ & $\mathbf{N}$ \\
$\mathbf{0}$ & & $\mathbf{H}$ & $\mathbf{S}$ & $\mathbf{K}$ & $\mathbf{W}$ & $\mathbf{1}$ & $\mathbf{2}$ & $\mathbf{A}$ \\
\hline 10 & $\begin{array}{l}\text { Harry } \\
\text { Setiawan }\end{array}$ & 92 & 72 & 70 & 70 & 71 & 0 & 73 \\
11 & $\begin{array}{l}\text { Juan } \\
\text { Kalyzta }\end{array}$ & 92 & 70 & 70 & 72 & 65 & 65 & 70 \\
12 & $\begin{array}{l}\text { Sanding } \\
\text { Riyanto }\end{array}$ & 93 & 65 & 65 & 72 & 65 & 65 & 69 \\
13 & $\begin{array}{l}\text { Kris } \\
\text { Setiawati }\end{array}$ & 75 & 66 & 70 & 70 & 71 & 60 & 67 \\
14 & $\begin{array}{l}\text { Grace A L } \\
\text { Simamora } \\
\text { Muhamad }\end{array}$ & 68 & 56 & 60 & 68 & 50 & 61 & 64 \\
15 & $\begin{array}{l}\text { Rifki } \\
\text { Adnan }\end{array}$ & 65 & 70 & 68 & 70 & 63 \\
16 & $\begin{array}{l}\text { Muhamma } \\
\text { d Iqbal }\end{array}$ & 67 & 65 & 70 & 70 & 72 & 68 & 62 \\
17 & $\begin{array}{l}\text { Aryabima } \\
\text { Yogi Angga } \\
\text { Putra }\end{array}$ & 76 & 67 & 65 & 68 & 72 & 60 & 49 \\
18 & $\begin{array}{l}\text { Muhamma } \\
\text { d Arya }\end{array}$ & 72 & 66 & 65 & 60 & 50 & 0 & 44 \\
Java & & & & & & \\
\hline & Java & & & & & &
\end{tabular}

Keterangan : NH=Nilai Hardware, NPS=Nilai Psikotes, NK=Nilai Kompetensi, NW=Nilai Wawancara, NP1= Nilai Project1, NP2=Nilai Project2, NA=Nilai Absensi.

Berdasarkan hasil perhitungan diatas maka didapatkan perankingan dari Total Bobot Evaluasi (TBE) seperti pada Tabel 5.

Tabel 5. Hasil Perangkingan berdasarkan TBE

\begin{tabular}{lll}
\hline No & \multicolumn{1}{c}{ Nama Alternatif } & TBE \\
\hline 1. & Muhammad Verdiansyah & 79.9 \\
2. & Juan Kalyzta & 73.6 \\
3. & Erika Nur Komalasari & 72.2 \\
4. & Sanding Riyanto & 72.1 \\
5. & Irennada & 71.9 \\
6. & Muhammad Rifki Adnan & 71.4 \\
7. & Nurul Azzahra & 70.7 \\
8. & Nur Fahmi Aziz & 70.3 \\
9. & Amirudin & 70.1 \\
10. & Selfiana Halfiana & 69.5 \\
11. & Kris Setiawati & 69.1 \\
12. & Kamil Salim & 68.8 \\
13. & Harry Setiawan & 68.3 \\
14. & Muhammad Iqbal A & 67.3 \\
15. & Muhammad Satrio A & 66.9 \\
16. & Yogi Angga Putra & 64.7 \\
17. & Grace A L Simamora & 61.9 \\
18. & Muhammad Arya Java & 53.8
\end{tabular}

\section{Rancangan Prototipe}

Tabel 6, Tabel 7, dan Tabel 8 merupakan struktur tabel utama yang digunakan dalam aplikasi sistem pendukung keputusan penentuan penerimaan Asisten Lab ICT :
Tabel 6. Tb kriteria

\begin{tabular}{llll}
\hline No & Nama Field & Type & Keterangan \\
\hline 1. & Kode_Kriteria & $\begin{array}{l}\text { Varchar } \\
(16)\end{array}$ & Kode Kriteria \\
2. & Nama_Kriteria & $\begin{array}{l}\text { Varchar } \\
(225)\end{array}$ & Nama Kriteria \\
\hline
\end{tabular}

Tabel 7. Tb_alternatif

\begin{tabular}{llll}
\hline No & Nama Field & Type & Keterangan \\
\hline 1. & Kode_Alternatif & $\begin{array}{l}\text { Varchar } \\
(16)\end{array}$ & Kode \\
& & Kriteria \\
2. & Nama_Alternatif & $\begin{array}{l}\text { Varchar } \\
(225)\end{array}$ & Nama \\
& & & Kriteria \\
\hline
\end{tabular}

Tabel 8. Tb_detailalternatif

\begin{tabular}{|c|c|c|c|}
\hline No & Nama Field & Type & Keterangan \\
\hline 1. & Kode_Kriteria & Varchar(16) & Kode \\
\hline 2. & Kode_Alternatif & Varchar(16) & $\begin{array}{l}\text { Kode } \\
\text { Alternatif }\end{array}$ \\
\hline 3. & Nilai & Integer(3) & $\begin{array}{l}\text { Nilai } \\
\text { alternatif }\end{array}$ \\
\hline
\end{tabular}

Prototipe aplikasi pendukung keputusan dikembangkan dengan bahasa pemrograman PHP dan perangkat basis data MySQL. Gambar 3 dan Gambar 4 merupakan contoh tampilan aplikasi yang telah dikembangkan pada penelitian ini. Pada Gambar 3 tampilan layar untuk menginput nilai alternatif dari masing-masing kriteria. Sedangkan pada Gambar 4 akan ditampilkan daftar hasil perankingan Total Bobot Evaluasi (TBE) dari semua alternatif di urutkan secara Ascending (urut dari nilai terbesar ke nilai terkecil).

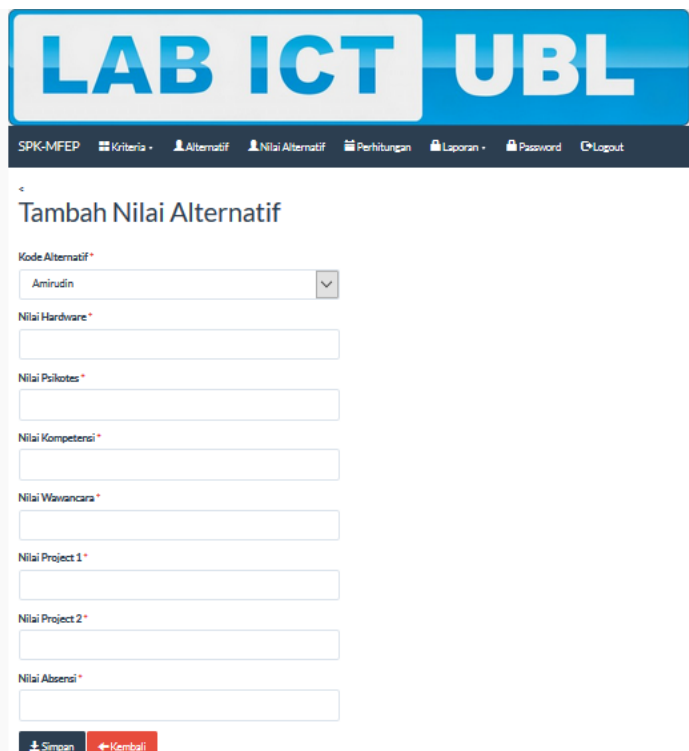

Gambar 3. Tampilan halaman tambah nilai alternatif 
Pengguna dapat menambahkan nilai alternatif dengan memilih nama alternatif (calon asisten) dan menginput nilai masing-masing komponen. Nilai yang diinputkan dalam rentang 0100. Setelah semua nilai diinput, pengguna dapat menekan tombol Simpan.

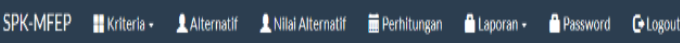

\section{Laporan Perhitungan Total Bobot Evaluasi}

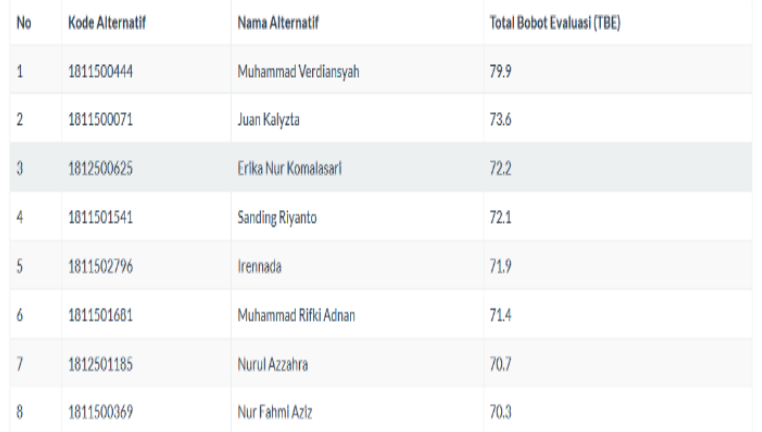

\section{Gambar 4. Laporan Perankingan TBE}

Gambar 4 menyajikan laporan perhitungan total bobot evaluasi (TBE) untuk setiap alternatif. Pelaporan disajikan secara terurut dari nilai TBE yang terbesar hingga terkecil. Nilai TBE berada pada rentang 0-100. Pada contoh laporan di Gambar 4, nilai TBE terbesar diperoleh oleh alternatif (calon asisten) dengan nama Muhammad Verdiansyah.

\section{Pengujian Sistem}

Pengujian yang pertama menggunakan metode pengujian perangkat lunak Black box. Menurut Roohullah Jan dan J. Watkins dalam (Jaya, 2018), Black Box Testing merupakan teknik pengujian perangkat lunak yang berfokus pada spesifikasi fungsional dari perangkat lunak. Untuk memastikan sistem bekerja dengan maksimal maka dilakukan pengujian sistem. Pada penelitian menggunakan pengujian sistem dengan metode black box. Hasil pengujian sistem dengan menggunakan metode black box terlihat pada Tabel 9.

Tabel 9: Hasil Pengujian Sistem

\begin{tabular}{llll}
\hline No & Halaman & Hal diuji & Hasil \\
\hline 1. & Login & $\begin{array}{l}\text { Notifikasi Login } \\
\text { Berhasil dan } \\
\text { masuk ke halaman } \\
\end{array}$ & Sukses \\
& & Menu Utama & \\
2. & Kriteria & Menu & Sukses \\
\hline
\end{tabular}

\begin{tabular}{lll}
\hline No Halaman & Hal diuji & Hasil \\
\hline & menampilkan & \\
& Kode Kriteria, \\
& nama kriteria, \\
& bobot, aksi untuk \\
& ubah dan \\
& hapus,tambah, dan \\
& proses pencarian \\
& kriteria
\end{tabular}

3. Alternatif Menu Sukses

menampilkan

Kode Alternatif, nama Alternatif, aksi untuk ubah dan hapus,tambah, dan proses pencarian alternatif

4. Transaksi Nilai

Menu

Sukses

Alternatif

menampilkan

kode alternatif, nama alternatif , semua nilai- nilai kriteria dan menginput ilainilai kriteria untuk masing-masing alternatif serta searching.

5. Transaksi Menu untuk Perhitungan

menampilkan ranking hasil

6. Laporan

$$
\begin{aligned}
& \text { Menu untuk } \\
& \text { laporan per } \\
& \text { alternatif dan } \\
& \text { menampilkan } \\
& \text { laporan ranking } \\
& \text { semua alternatif / } \\
& \text { Total Bobot } \\
& \text { Evaluasi }
\end{aligned}
$$

Sukses

$\begin{array}{ll}\text { 7. Logout } & \begin{array}{l}\text { Menu untuk keluar Sukses } \\ \text { dari aplikasi }\end{array}\end{array}$

Sukses

Berdasarkan hasil pengujian yang dilakukan terhadap sistem yang dibangun, sistem berjalan optimal sesuai dengan kebutuhan yang diperlukan. Dimana sistem yang dibangun sesuai dengan memberikan hasil sesuai dengan yang diinginkan oleh user. Seluruh fungsionalitas sistem sudah diujicoba dan terbukti dapat berjalan dengan baik. 
Selain menggunakan metode Blackbox, pada penelitian ini juga dilakukan pengujian persepsional dengan metode pengujian ISO 9126. International Organization for Standarization (ISO) dalam ISO strandard 9126 telah mengusulkan beberapa karakteristik untuk melakukan pengujian terhadap kualitas sebuah perangkat lunak. (Andoko et al., 2018), ISO-9126 mengidentifikasikan enam karakteristik sebuah perangkat lunak dikatakan berkualitas, yaitu functionality, reliability, usability, efficiency, maintability dan portability. Dalam sistem pendukung keputusan penentuan penerimaan Asisten lab mengusulkan beberapa karakteristik functionality, realiability, usability, efficiency untuk melakukan pengujian terhadap aplikasi tersebut

Berdasarkan jawaban dari 7 (tujuh) responden yang mengisi kuesioner indikator kualitas perangkat lunak menurut ISO 9126, dapat diukur dengan Persamaan (3).

$\%$ Skor $=\frac{\text { Skor Aktual }}{\text { Skor Ideal }} \times 100 \%$

\section{Pengujian ISO 9126}

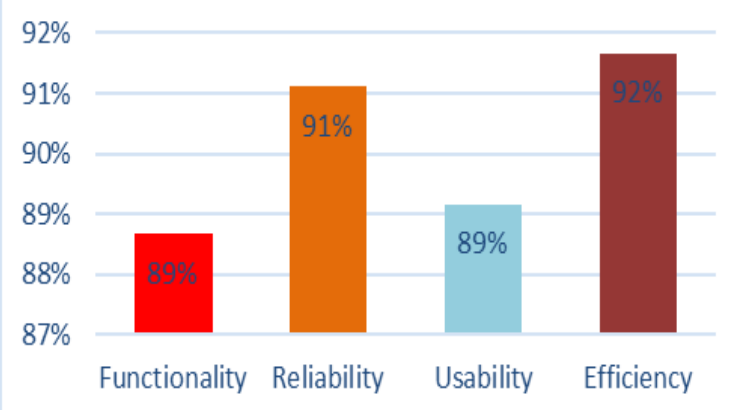

Gambar 5. Hasil Pengujian dengan ISO 9126

Berdasarkan analisis data yang diperoleh dari kuesioner, dapat disimpulkan bahwa total keseluruhan skor hasil pengujian kualitas aplikasi berdasarkan empat aspek kualitas perangkat lunak aplikasi (Functionality, Reliability, Usability, Efficency) dengan standar ISO 9126 adalah $90 \%$ dan termasuk kategori Sangat Baik. Untuk functionaly dan Usability perlu ditingkatkan karena nilai yang didapatkan kurang dari $90 \%$.

\section{SIMPULAN}

Berdasarkan perhitungan serta perancangan sistem pendukung keputusan, sehingga disimpulkan bahwa pengambilan keputusan penentuan penerimaan asisten
Laboratorium Information and Communication Technologi (LAB ICT) dapat dilakukan dengan menggunakan Metode Multi Factor Evaluation Process (MFEP). Pemberian bobot faktor kriteria akan mempengaruhi penilaian dan hasil perhitungan metode MFEP. Hasil uji coba untuk perhitungan MFEP yang dilakukan oleh sistem sesuai dengan hasil pengujian yang dilakukan secara manual. Berdasarkan pengujian Sistem dengan metode Black Box maka sistem berjalan secara maksimal sesuai dengan fungsinya. Berdasarkan pengujian aplikasi dengan ISO 9126 dengan menggunakan karakteristik functionality, realiability, usability, efficiency didapatkan nilai 90 $\%$ atau sangat baik.

\section{DAFTAR REFERENSI}

Andoko, Alfiarini, \& Yanto, R. (2018). Penerapan Metode Multi Factor Evaluation Process Pada Sistem Pendukung Keputusan Penentuan Kelayakan Pemberi Pinjaman ( Studi Kasus NSC Finance Kota Lubuklinggau ), 4(2), 113122.

Diwanda, S. A., Ode, L., Sagala, H. S., Informatika, J. T., Teknik, F., \& Oleo, U. H. (2016). Sistem pendukung keputusan penilaian kinerja karwayan menggunakan metode Multi Factor Evaluation Process pada PT. Konsuil Wilayah Sulawesi Tenggara. semanTIK, 2(1), 341-348.

Djunaedi, A., Subiyakto, A., \& Fetrina, E. (2017). SISTEM PENDUKUNG KEPUTUSAN PENILAIAN KINERJA PEGAWAI (Studi Kasus : PT . PLN (Persero Distribusi Jakarta Raya Area Pondok Gede)). Jurnal Sistem Informasi, 10(1), 37-44.

Hutabri, E. (2015). SPK dalam pemilihan siswa kelas unggul menggunakan metode MFEP di SMP N 2 Solok. Edik Informatika, 1(2), 55-63.

Jaya, T. S. (2018). Pengujian Aplikasi dengan Metode Blackbox Testing Boundary Value Analysis. Jurnal Informatika: Jurnal Pengembangan IT Poltek Tegal, 03(02), 4548. https://doi.org/10.30591/jpit.v3i1.647

Latif, L. A., Jamil, M., \& Abbas, S. H. (2018). Sistem Pendukung Keputusan Teori dan Implementasi. DEEPUBLISH.

Purnomo, R., Nurdin, A., \& Nangi, J. (2017). Penerapan Multifactor Evaluation Process (MFEP) untuk Penilian Guru (Studi Kasus: 
MAN 1 Kota Kendari). Seminar Nasional Riset Kuantitatif Terapan, (April), 76-79.

T. Henny Febriana Harumy, I. S. (2016). Sistem Penunjang Keputusan Penentuan Jabatan Manager Menggunakan Metode MFEP pada CV. SAPO DURIN. Seminar Nasional Teknologi Informasi dan Multimedia 2016, 6-7.

Turaina, R., Gustia E, \& Cici. (2017). Sistem Penunjang Keputusan Penerimaan Calon Tenaga Honorer Di Sma N 1 Junjung Sirih Kab. Solok Menggunakan Metode Multifaktor Evaluasi Proses (Mfep). Jurnal Momentum, 18(2), 60-66. https://doi.org/10.21063/jm.2016.v18.2.6066 